\title{
Revisiting Islamization of Courses in Economics with Special Emphasis on the Operational Aspect
}

\author{
Ataul Huq Pramanik ${ }^{*}$ \\ Department of Economics, International Islamic University Malaysia, 53100 Kuala Lumpur, Malaysia
}

\begin{abstract}
Knowledge immune from the moral and ethical principles based on a belief system as that of Islam has failed to address the hydra-leaded problems facing the world. Knowing about truth is possible not just by using acquired knowledge based on human reasoning or intellect. In other words, knowing is about 'becoming' or 'being'. The state of 'being' requires a continuous process of searching for the truth i.e. reality. However, given the diversity in human knowledge based simply on rationality and reasoning, it is a stupendous task to integrate the acquired knowledge of a discipline like that of economics with revealed knowledge i.e. on Islamic world view (IWV). This study attempts to identify the existing courses in Economics based on so-called conventional wisdom and suggest the process of integrating the knowledge of IWV usng the sources derived from the Quran, Sunnah, Qiyas and ljtihad. As for the operationalization, this study involves different potential stake-holders such as, institutions, teachers, students, sharia scholars, parents, and lastly the markets as components of demand and supply side.
\end{abstract}

Keywords: Islamization, revealed and acquired knowledge, conventional economics, stake-holders.

\section{BACKGROUND}

To acquire knowledge is vital for every human being regardless of his faith. All the living religions either revealed or non-revealed put equal emphasis on acquiring knowledge. ${ }^{1}$ Islam as one of the revealed religions has a special emphasis on acquiring knowledge ${ }^{2}$ by its followers -the Muslims. The holy Quran being the word of God as well as the primary source of the religion of Islam commands all human beings to read in the name of God who has created this world with everything there in. ${ }^{3}$ The association of

*Address of correspondence to this author at the Department of Economics, International Islamic University Malaysia, 53100 Kuala Lumpur, Malaysia; Tel: 603-61964621; Fax: 603-6196 4850; E-mail: ataul_huq@yahoo.com

\footnotetext{
${ }^{1}$ According to Al-Attas (1978) all knowledge comes from God since it has been understood to mean the Holy Quran; the Revealed Law (Shariah); the Sunnah, Islam, Faith (Iman); spiritual knowledge, wisdom and Gnosis He further elaborates that the first kind of knowledge is given by God through revelation to man; and this refers to the Holy Quran. The Sunnah of Holy prophet (pbuh) implying the manner of interpreting God's law (shariah) in daily life and practice is also part of the knowledge. The shariah is God's law embodied in the Holy Quran and manifested in word (qawl) model action (fi'il) and silent confirmation (taqrir) in the Sunnah which includes spiritual knowledge and wisdom. So, the Holy Quran, the Sunnah, the shariah, ilm al-dunniyy and hikmah (knowledge and wisdom of this world) are the essential elements of the first kind of knowledge. The second kind of knowledge that can be acquired through man's acts of worship and devotion is the spiritual knowledge (Al-Attas (1978), pp. 136-139).

${ }^{2}$ According to Ali Ashraf (in El-Edrus, 1990, Foreword) knowledge comes from knowing. Knowing, in its essence, is 'becoming' and 'being'. The 'Being' ofa person is thus a continuous process of transformation. There is no gap in true knowing and becoming. The gap generally envisaged in some western philosophy between knowing one thing intellectual and not becoming emotionally totally affected by it, in other words, doubts are still lingering in the mind about certainty of the thing known. According to the Quran so long as this gap exists, a person has not acquired knowledge. What the person acquires is conjectural knowledge.

${ }^{3}$ That knowledge is one of the central concerns of the Quran becomes evident from the following verses which say" Are those equal, those who know and those who do not know?" (39:9) and again Quran says, "Are the blind equal with those who see?" (13: 16) For further details on the Quranic value of knowledge see Al-Edrus note 6 chapter 1 . Al-Edrus has examined the theory of knowledge in the Quran from various angles. In this book he has also presented the views of different scholars -both Muslims and non-Muslims on the concepts, history as well as the theory of knowledge.
}

learning or acquiring knowledge with the creator, God Himself and His creation has, in fact, set the precondition for the seekers of knowledge. Another aspect of knowledge is the search for truth. In the quest for finding that truth, we acquire knowledge of anything through our understanding of that thing. A true believer in God is required to search for knowledge that is coming from God called revealed knowledge (wahy). The second source from which knowledge comes is through the application of human intellect or reasoning $(A q l)$ in order to understand the laws and relationships pertaining to human behaviour. This study will attempt to focus on how to transform the acquired aspect of human knowledge in one of the disciplines called economics and integrate it with the revealed knowledge the basis of which can be both primary source, the Quran and the secondary sources i.e., the Sunna together with the tertiary sources i.e., consensus (ljtihad or ljma) and analogy (Qiyas). ${ }^{4}$

\section{WHAT IS ISLAMIZATION}

The study of economics like any other branches of knowledge i.e., history, sociology, -.psychology, arts, science and geography etc. must, therefore, be guided by God's perception of that particular aspect of knowledge. This perception is made available to the

\footnotetext{
${ }^{4}$ The Holy Quran says (24: 19) God has absolute knowledge of everything whereas man knows but little. So, man is totally incapable of understanding and knowing God's knowledge except with God's will and permission. Only with His guidance will a man be given insight into the knowledge of God (2:255) God has taught in al-Quran all kinds of knowledge for the benefit of mankind so that man believes in al-Quran and use it as a source of guidance (hidayah) 55 1-4). The importance of Quran as the most fundamental source of knowledge as approved by God also becomes evident from many other verses in the Quran (e.g., 17:82; 96:5; 39:9; 4: 162; 12:76; 53:28; 102:57; 69:51; 89:27-28; 2: 26 and many more).
} 
human being through the revealed knowledge. ${ }^{5}$ The sources of the knowledge as desired by God could be both primary comprising the holy Quran as well as the secondary comprising the tradition of the prophet (p.b.u.h.). The secondary sources also include the principles, laws and precedences in conformity with the shariah comprising the Quran and the Sunnah. Any knowledge that is acquired by man i.e., conjectural knowledge (zanu in arabic) but does not conform to the criteria as laid down in the above stated primary and secondary sources needs either to be rejected or be brought in line with the ethical foundations as required by the broader context of the shariah. ${ }^{6}$ So, the process of transforming such acquired knowledge in any discipline in the light of the Quran and the Sunnah including the laws and principles to be deducted there from with the help of ljma and Qiyas can be called as Islamization.

Islamization process has been explained by different scholars in different ways. According to Faruqi (cited in News Bulletin of 110M, Oct. -Dec. 1995) it requires that 'every claim pass through the tests of internal coherence, correspondence with reality, and enhancement of human life and morality'. This process, according to Kamal Hassan (Also cited in News Bulletin 1995) may also mean an exercise involving critical appreciation, elimination, separation and reconstruction. According to Abu Sulayman (1989, pp. 141-143), since Islamization implies correct direction, correct objectives, and correct philosophy it is reformation in nature, constructive, ethical, rightly guided, and tawhidi.

What the above stated ideas seem to suggest is that Islamization of economics like any other discipline must be comprehended within the framework of Islamic world view whose very foundation is based on moral, ethical and spiritual belief-system as enshrined in Islam. Despite the differences existing in detailed conceptual matters relating to Islamization of

\footnotetext{
${ }^{5}$ All the four principal sunni schools of jurisprudence comprising the Hanafi the Maliki, the Shafie and the Hanbali accept the validity of the four sources enjoined by" the sharia; first being the holy Quran, the second, the sunna and tradition of the prophet (pbuh), the third, consensus (ljma) and fourth, the analogy (Qiyas). The Shiites accept only the first three sources but replace the fourth one, Qiyas by reason i.e., Aql. For details on these sources see Nomani and Rahnema (1995, pp. 1-16).

${ }^{6}$ The attempts to bring the acquired knowledge inconfromity with the shariah are widely discussed by the scholars (liiT, IKS-5, 1989 part VI; Sadeq, 1995; Arif, 1987; Molla et. al (ed.), 1988), chap. 1; Moten et. al. (ed). 1990, Part I(c); Kahf, 1979, Chap. I; Abu Sulayman in ATP, USA, 1976, pp. 8-42 under the concept of methodology. Despite differences in the style of their arguments on the topic. Particularly dealing with the primary, secondary and tertiary sources, most of them agree that there is a need for ljtihad to deal with the newly emerging economic problems and issues facing the mankind in general and Muslims in particular.
}

Economics, ${ }^{7}$ the shariah compatibility as perceived from the primary and secondary including tertiary sources (Farhad \& Ali, 1995) emerges as the fundamental basis in the efforts towards Islamization. Having briefly delved on the conceptual aspect of Islamization, let us briefly examine the different dimensions of the concept of economics and their implications for Islamization.

\section{WHAT IS ECONOMICS AND ITS RELEVANCE TO ISLAMIZATION}

Conventional economics as opposed to Islamic economics, as understood by a layman, studies human behavior in the ordinary business of life. Although, this definition appears quite simplistic, it is perhaps the most comprehensive definition of economics in the sense that it appears to cover all that we perform in terms of thinking, engaging in useful activities pertaining to earnings and spendings, eating, drinking, resting, travelling, sleeping and what not, in our daily life. That time is one of the central pre-occupations in contemporary industrial society becomes evident from Blyton's (1992) work on times, work and organization. ${ }^{8}$ The comprehensiveness of this definition explains why Keynes, the father of modern. Macroeconomics said the four-fifths of what we do and think centers round a single activity called economics. L. Robbin's definition, among many others, appears to be highly technical as well as most commonly used one. According to Robbins, economics studies human behaviour as a relationship between ends and scarce means which have alternative uses. So, professionally speaking, economics is concerned with the efficient utilization or management of limited productive resources for the purpose of attaining the maximum satisfaction of human material wants.

Whatever way the traditional or secular economics is defined it appears to be characterized by material aspects for the temporal world, unlimited wants within the purview of limited or scarce means and maximum satisfaction of a self-interested or egoistic man. To be

\footnotetext{
${ }^{7}$ Islamization of knowledge represents a type of knowledge based upon revealed norms and ideals of the Divine message. It stresses the need for action to achieve mastery and command both in the field of legacy and modern sciences and making provisions', for acquiring the required skills and resources for it (IIIT, IKS No.1, 1989, pp. 84 - 93).

${ }^{8}$ Attitudes to and experience of time are conditioned by social life, particularly by membership of an occupational group. Time at work has to be understood within the context of a western culture with the dominant perspective of an economic orientation to time. This tends towards times rationalization and commodification. This commoditized approach to time has been highlighted as of crucial significance to the way much work is organized. Blyton et. al. (1992, p. 3).
} 
specifically speaking, in a world of consumers and producers, the attainment of maximum satisfaction in terms of utilities and profits being measured in quantitative terms is the single most purpose of human existence. The degree of fulfilment of this purpose is further preconditioned by the presence of a rational behaviour of both consumers and producers such as, the measurability of utilities and profits, the private ownership in absolute sense, the economic freedom at the individual level decision-making in an environment of a freely competitive market.

\section{SECULAR WORLD VIEW (SWV) IN COMMON ECONOMICS}

Conceptually speaking, common economics deals with the temporal world where individualism, quantitative measurement of happiness, absolute ownership of resources in all conceivable forms, unregulated market and social Darwinism manifest through the survival of the fittest emerge as the key elements. It seems common economics is partial and obviously lacks comprehensiveness, coherence and ethical considerations. As if, beyond human beings, nature and environment, nothing else exists. Because of the failure of common economics to conceive of a third and most powerful force that binds together human being with natural kingdom, the existence of God as manifest through the unity of the creator and of creation, unification of truth and knowledge, unity of life and unity of humanity ${ }^{9}$ is virtually denied. This explains why common economics comes under the preview of secular world where God, even though, exists but is expected to play no role. Man being considered as the Supreme Being is empowered to dominate the entire natural kingdom in the way he likes as long as his own interest is served.

There is no denying the fact that common economics even in the presence of all the preconditions has failed to satisfy even the barest minimum of human material wants in this temporal world. This observation holds for all countries regardless of whether it accepts (i.e., Christian world) or rejects (i.e., Communist world) the role of the third and most powerful force i.e., God in terms of how to make use of the nature for the satisfaction of human material wants. Despite tremendous advancement in terms of new tools, new institutions, new strategies, policies and goals, the basic problems of production, consumption and distribution confronting the human

${ }^{9}$ IIIT, IKS, No.1, 1989, Chap. IV. beings could not be resolved. Not only that the pursuit of two objectives of maximizing profits and of utilities has, in fact, turned the economic man into a selfcentered man with no moral scruples. Regardless of the degree of material achievements either at the micro or macro level, deprivations and dissatisfactions have destroyed the whole social fabrics. ${ }^{10}$

This warrants the need for Islamizing common economics by way of testing the elements of common economics through the moral filter. Before going to examine the methods and problems involved in the Islamization effort it would therefore be appropriate to discuss the reasons why common economics needs to be tailored to fit into the Islamic world view in general and Islamizing of economics in particular. However, our intention here is not to deliberate on the detailed conceptual and other dimensions of Islamic world view, as such. ${ }^{11}$

\section{ISLAMIC WORLD VIEW (IWV) IN COMMON ECONOMICS}

It would not be wrong to say that most of what characterizes common economics fail to pass the moral test (vide Chart 1). Islamic world view providing the foundation for applying Islamic economics or what we call shariah compatible aspect of common economics is based on moral, ethical and spiritual dimensions of the value system. Islamic world view (IWV) assumes God consciousness while performing economic activities as reflected through muamalah. In other words, IWV implies the omni-presence of Godconsciousness in the entire thought process of an individual as consumer and producer. As a value system this view assumes the existence of God, the creator in the first place followed by the entire natural kingdom -the universe geared to making the existence of human being meaningful in this world. ${ }^{12}$ So, the

\footnotetext{
${ }^{10}$ In his book Vadillo (1991) has highlighted the exploitative aspect of secular economic operations either through riba or monopoly power. According to him, the end of economics is because of unjust practices being pursued by the Western free market capitalistic system.

${ }^{11}$ According to Acikgenc (1996) a world view is the mental domain within which the mind functions. A world view is not constructed, but rather formed in the mind of an individual in a casual manner. In the regard, the culture, technology, scientific and speculative ideas acquired through one's education together help form and kind of habit that is dominant in one's life. This, in turn, contributes to the formation of a particular worldview of an individual being depending on whether he believes in the unity of God (Tawhid), the messenger (Risalah), vicegerency (Khilafah) in the hereafter (Akhira) and unity of mankind (universal brotherhood).

${ }^{12}$ Chapra (1992, pp. 201-213) mentions of three fundamental principles namely tawhid (unity), khilafah (vicegerency) and adalah (justice) that not only frame the Islamic world view but also constitute the fountain head of the maqasid alshariah (goals of shariah) and the strategy. While tawhid implies divine unity, khilafah inlcudes universal, brotherhood, trusteeship, humble lifestyle, and human freedom, the justice (Adalah) includes need-fulfilment, lawful means of earning, equitable distribution of income and wealth together with growth and stability.
} 
three-way relationships as can be transpired through Islamic world view -man-man, man-nature and manGod within the context of faith, risalah and Akhira have made man the most accountable to God for how to live and act as a trustee as well as vicegerent in this world. Having the status of superior most being among the God's creations, ${ }^{13}$ man is given freedom to choose either to live like an economic man or an Islamic man. As such, while the entire thought process of an economic man within the context of materialconsciousness as reflected in the ordinary business of life will form a world view of his own only compatible with secular world. But an Islamic man within the context of God-consciousness will form a world view compatible with Islamic world.

An Islamic man being the believer of this world and the world hereafter, instead of maximizing his material satisfaction, is committed to maximize the pleasure of God alone i.e., 'Falah'. This, in fact, is the main purpose of human existence in this world. To maximize the pleasure of God, man is encouraged to be modest, compassionate and just in everything and not a mere maximizer of anything beneficial to him only in this world, I regardless of his role as a consumer, producer, buyer, seller, earner, spender, saver, investor, employer, employee etc. etc. The key word for all these agents of change is moderation (Kamal Hassan, 2011 \& 2013).

An Islamic man being guided by the three-way relationships i.e., Tawhid, Risalah and Akhirah $^{14}$ is expected to pursue collective interest in place of selfinterest, enjoy being trustee rather than being absolute owner, share rather than compete, live not for himself alone but along with others. Apart from accepting internalizing and practicing the five basic tenets of Islam, ${ }^{15}$ an Islamic man is also enjoined to distinguish good from bad, virtues from vices, dos from don'ts, benevolence from exploitation and just from unjust. All these attributes of an Islamic man are expected to be possessed by everybody in his capacity, either as individual or head of the family, community,

\footnotetext{
${ }^{13}$ The Quran is quite emphatic in this regard: "God has made the ships (the winds which drive them) subject to you..., and the rivers... the sun and moon, day and night." (Quran 14:32-83). The Quran further says He has made the seas subservient to you, camels and cattle all that is on earth and in heaven (Quran 16: 14; 22:36-37, 22:65; 45: 12).

${ }^{14}$ God has created man capable "in the best of forms" (Quran 95:4). He has given him all the equipment's necessary to achieve fulfilment of the divine imperatives. Above all, God who created everything perfect... created man out of earth Perfected and; breathed into him of His own spirit. He has bestowed upon him" his hearing, his sight and his heart (Quran 32:7-8)."

${ }^{15}$ The five tenets of Islam include the belief in Allah, belief in his messanger, the prophet (pbuh) and His Book, establishing prayer, paying zakah (poor's due), and performing Hajj.
}

organization, institution or state. The need for Islamization of common economics, therefore, involves, the transformation of an economic man guided by all the attributes of a secular world view into an Islamic man guided by all the attributes of Islamic world view as delineated above.

\section{ISLAMIZING COMMON ECONOMICS OR ISLAMIC ECONOMICS?}

The question now arises as to whether this transformation process would be served better by Islamizing common economics in terms of moral filter or by introducing Islamic economics as can be derived from the primary and secondary sources only. There are opinions in favour of both. These who are in favour of the former but against the later argue that since the already developed positive common economics contains lot of elements some of which are not only universally true but also value neutral, an Islamic man can benefit from them by way of critical appreciation, elimination, separation and reconstruction of these theories and concept. ${ }^{16}$ This boils down to examining common economics through the moral filter. Those who are in favour of the later but against the former argue equally strongly by saying that the concepts, theories and laws developed so far are the direct products of secular western thought process based on material world-consciousness. As such, they fail to pass through the tests of internal coherence, correspondence with reality, and enhancement of human life and morality within the perspective of Islamic world view based on material and spiritual world-consciousness. Given this limitation, our attempt here is directed towards the operational aspects of Islamizing common economics. What follows will try to answer the fundamental questions of 'Islamizing for whom' 'how to Islamize' and 'by whom'.

\section{ISLAMIZATION 'FOR AND BY WHOM?'}

The Islamization effort involves two aspects demand and supply. The demand side involves the

\footnotetext{
${ }^{16}$ Professor Kamal Hassan mentions of seven processes involved in the efforts towards Islamization of any discipline. These processes include decentralisation; critical review; critical appreciation and revision of the existing body of knowledge; filtrations of the existing body of knowledge by the filter of tawhid; integration and infusion; rejection and demolition of certain existing structures within the body of knowledge and finally reconstruction and reformulation of the discipline to come up within a respectable body of knowledge comparable to what is best in the conventional knowledge that can withstand the test of scientific scrutiny. In fact, the processes involved in the Islamization as listed above are mutually inclusive and not exclusive in the sense that all these processes can be achieved through a single process involving the use of 'moral filter to seek the truth'.
} 
students and their parents, the institutions, organizations, firms and enterprises in the role of employers. The supply side involves primarily-the academic institutions working within the objectives of state machinery for imparting knowledge. The teachers, philosophers and thinkers are equally important in this process in so far as their role in imparting appropriate knowledge is concerned. Abu Sulayman (1989, pp. 149-153) has rightly emphasized the role the Islamic academic institutions are expected to play in achieving the goals of Islamization. In the efforts towards Islamization it will be necessary to direct the energies of researchers, scholars, teachers and students toward the new Islamic intellectual framework. Abu Sulayman has also mentioned of five steps required to be undertaken by the Islamic educational institutions in the Islamic process. It appears that the most crucial role is to be played by the society and the value system transpired through it.

The society as a single entity plays a multidimensional role. It influences the value system of the parents, students and employers from the demand side and also creates appropriate environments for those who are acting from the supply side. The society of which producers, consumes and employers form the individual entities also provides the testing as well as the breeding ground for evolving new ideas, assumptions, principles, laws and theories which, in turn, finally govern the society. The mere enforcement of decisions on Islamization of economics from one of these two sides will not deliver the desired results. The half-hearted attempt from one side may achieve short term political goals but may likely to jeopardize the long term goals of a fully-fledged Islamic society where the fresh need for Islamizing common economics may not be warranted.

That there is need for appropriate economic environment as a testing ground for the Islamization process becomes evident from the emergence of Islamic financial system. This, perhaps, explains why the Islamic Banking system gained so much importance in a number of countries regardless of religious faiths' since the latter half of the 1970s. It was during that time, the huge oil-surplus deposited in the Western interest-based banks was lent out to the capital-shy countries on easy term and conditions. The failure to make productive utilization of the loan brought disaster in the form of debt burdens to most of the borrowing countries and in particular the LatinAmerican countries. The cumulative effect of the principal borrowed along with the compound interest charges reached beyond the ability of some big borrowers. The interest-based lending of mid 1970s can be held responsible for triggering demand-pull as well as cost push- inflation, the spiraling effects of which contributed to unemployment, erosion of purchasing power and subsequently the world-wide recession of early 1980s from the grip of which the world is yet to recover. It was because of this failure of the conventional interest-based financial system that the Muslim countries got the impetus of experimenting with the novel Islamic financial system. Based on this experience one can equally strongly argue that the lack of initiatives by the Muslim countries to partially replace secular fiscal system by Islamic fiscal system failed to create a proper environment for the experiment of another most fundamental institution of Islam i.e. Baitul Mal through zakat implementation.

At the moment the Muslim world as a whole with the exception of perhaps Iran (Valibeigi, 1991) and to some extent Saudi Arabia has failed to create appropriate environment for Islamization process. However, the attempts are being made in countries like Sudan and Pakistan for creating a testing ground for gradual Islamization of the society in general and the economy in particular. Libya's attempt to ensue social justice in all spheres of life by way of implementing Islamic brand of socialism has created controversies in the Muslim world although Islamic social order is accepted as one of the most significant cardinal principles of Islam.

\section{CREATING APPROPRIATE ENVIRONMENT FOR ISLAMIZATION}

The demand and supply side involves the interactions among three namely, the students, and their parents, the employers i.e., the market and the institutions operationalizing through state policies. In other worlds, the products (students) the market and the producers (firm) i.e., the academic institutions form the important components in the Islamization process. The success of Islamization effort will, therefore depend on how the problems confronting these components are addressed to:

As for the students and parents are concerned, the curriculum on economics particularly from the secondary level needs to be redesigned with appropriate mix of general as well as religious inputs. The secondary level including the pre-university or matriculation should provide enough choices for choosing alternative courses that fit into their future plan of study at the tertiary level. The existing course 
on common economics beginning from the standard Nine up to standard Twelve (from 9th to 12th year of Education at the secondary level) will be required to introduce to the students some basic economic ideas from the secular as well as Islamic world view (vide Chart 1). This course can be taken by the students regardless of their religious and ethnic backgrounds. Thus, the curriculum on common economics at the preuniversity level is expected to create an urge both among the students and their parents to go for higher studies in Islamic Economics.

Having gone through the existing courses on common economics designed to suit the interest of the secular world, the students seem to have failed so far to appreciate the beauty Islamic Economics or Islamized part of common economics (vide App.). Thus, the primary aim of this newly designed courses on Islamized economics is not merely to impart additional knowledge based on the primary and secondary sources of shariah but also to prepare the new seekers of knowledge to internalize the core values such as moderation, compassion, cooperation, sharing, growing consciousness for needs and not affluence and practice them in the real life world. This is to demonstrate the practicability of the ideas as enjoined by the universal religion of Islam. In fact, a new breed of consumers and producers will be produced through the process of imparting knowledge. It needs no mentioning that the existing knowledge in common economics has been most successful only in producing a materialistically oriented economic man as opposed to Islamic man who is ethically guided with all the attributes of IWV as can be evidenced from Chart 1.

Production and consumption comprise the two most fundamental economic activities. The producers are usually induced by the market under SWV to produce goods and services regardless of the socio-economic standing of the demanders. Given the income inelastic $\sim$ nature of the essentials and the income elastic nature of the items of luxuries and comforts, the market is always bent towards producing more of non-essentials compared to essentials as the economy grows. Our new breed of consumers and producers are expected to emerge in terms of creating appropriate environment required both for implementing and testing the knowledge gained through Islamization of Economics together with other behavioral disciplines.

The third and most important element involved in the process of Islamization is the academic institution meant for imparting knowledge. Of this institution, teachers occupy a central position. Since our Islamization effort requires scholars having knowledge both in common economics and in the sources of sharia-based knowledge in Economics, existing teaching methodology needs to be overhauled. . The existing style of teaching based on preparing lectures from the available text/reference books on common economics will no longer be suitable for teaching Islamized economics or Islamic economics. This is because the teaching of Islamic economics requires the knowledge and understanding of shariah-based knowledge in economies, too. The new system will require a continuous dialogue between a western trained economist and the Ulama having a reasonably good grasp over the basic ideas on economics in line with the shariah. Such a dialogue will be redundant for those scholars who have gained expertise both in common economics and in the shariah.

The new system warrants a substantial part of the class lecture needs be prepared based on the continuous dialogues among the relevant professionals as classified below. The subject matter of the dialogue will have a focus on ideas, theories and examples pertaining to the relevant taught courses on common economics some of which are presented in App. Chart I. The issues of dialogues (vide Chart I) will be decided beforehand to facilitate preparation and active contribution by the participants. Based on the similar attempt by Anas Zarqa (1988, pp. 63-64) the professionals under consideration required to be involved in the dialogue process can be classified under four main categories:

The successful implementation of Islamizing common economics will depend on the availability of scholars under categories $1 \& 2$. The dialogue process warranted by this process will require the recruitment of teachers under these two categories. In view of the very limited availability of teachers under category 2 , at least two or three teachers under category I will be needed to facilitate the preparation of class lectures based on continuous dialogue process in the department. The professionals with practical experience like Umar Chapra, Ziauddin ahmad, Khurshid Ahmad, Nizatullah Siddiqui, Anaszarqa, Monzer Kahf, Akram Khan to mention a few under category 2 can be invited occasionally to help resolve the tricky issues discussed as per Chart $\mathbf{1}$ and App. Chart I. It is expected that with the help of this dialogue process lot of current debates pertaining to deductive or inductive methods of Islamizing economics 
(Sadeque, 1995; Khan and Anas Zarqa in Molla et. al., 1988; ATP, 1976, Aidit, 1989 among many others referred to in this study) can be resolved.

Under Category I, the scholars in shariah with some knowledge of economics will be invited to contribute to the new principles and theories of Islamic or Islamized economics as well as providing answers to resolve the emerging modern problems (vide Chart I);

Under Category II, those scholars having expertise both in shariah and economics will be invited to

contribute to search positive postulates and statements pertaining to economics as evidenced in the shariah;
Under Category III, the scholars having expertise in common economics with some understanding of shariah will be invited to deliberate on such important current macro but I positively focused issues namely, factors promoting or inhibiting growth, factors contributing to inflation, low productivity, recession and unemployment etc.;

Under Category IV, the scholars having expertise only in economics may deliberate on the analysis of the consequences of the positive aspects of Islamic economics such as Islamic taxes, incentive effects of zakat and other voluntary contributions like waqaf, sadaqah etc.;

\section{APPENDIX: CHART 1}

\section{Process of Islamizing Some Fundamental Economic Ideas}

\section{Through Dialogues A}

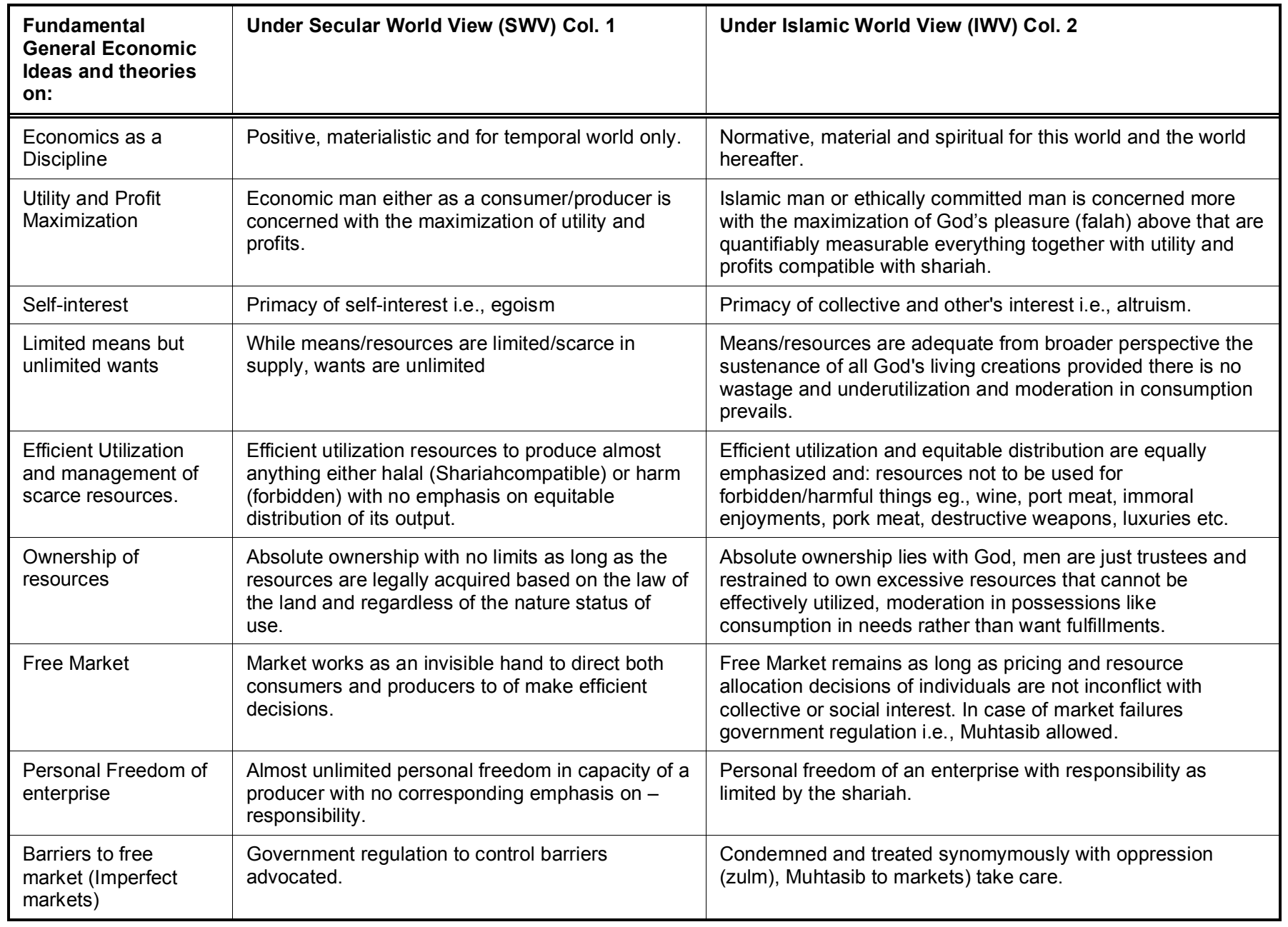




\begin{tabular}{|c|c|c|}
\hline $\begin{array}{l}\text { Government } \\
\text { intervention }\end{array}$ & $\begin{array}{l}\text { Government's existence only for public/social } \\
\text { goods, governments' regulatory policies are } \\
\text { allowed just to allow the market to work freely and } \\
\text { no to intervention for ensuring social justice. }\end{array}$ & $\begin{array}{l}\text { Much wider role of government intervention: through the } \\
\text { institution of Muhtasib or Ombudsman to ensure justice for } \\
\text { consumers/producers, buyers/sellers, regulate as well correct } \\
\text { market forces. }\end{array}$ \\
\hline Inequality & $\begin{array}{l}\text { Any amount of inequality is tolerated as long as it } \\
\text { results from free market freedom of enterprises, no } \\
\text { or limited }\end{array}$ & $\begin{array}{l}\text { That much of inequality which results, from differences in } \\
\text { talent, skills, hard work, experience, legal inheritance } \\
\text { intervention from government, for is tolerated but unethical } \\
\text { factors, unjust unfettered absolute ownership policies } \\
\text { promoting gross inequalities are in favor of perpetuating } \\
\text { unequal opportunities are strongly discouraged. }\end{array}$ \\
\hline Poverty & $\begin{array}{l}\text { To be taken care of by free market forces, no } \\
\text { intervention of any form is by advocated although } \\
\text { lately, social welfare system introduced with all the } \\
\text { concomitant negative effects morality, } \\
\text { unwillingness work hard, total supply of labour and } \\
\text { productivity. }\end{array}$ & $\begin{array}{l}\text { Since poverty leads to disbelief, it needs to be eradicated } \\
\text { even by intervention by government with restrictions imposed } \\
\text { on e some of the fundamental economic ideas on as stated } \\
\text { above. }\end{array}$ \\
\hline $\begin{array}{l}\text { Growth, Progress or } \\
\text { Change }\end{array}$ & $\begin{array}{l}\text { Only measured in quantitative terms by GNP/GDP } \\
\text { or expanding opportunities or capabilities and } \\
\text { avariciousness promoting growth; excepting those } \\
\text { assumptions like are maximization of material } \\
\text { gains as required under fundamental general } \\
\text { economic ideas, no other positive or negative } \\
\text { values are referred to. }\end{array}$ & $\begin{array}{l}\text { Essential for getting rid of poverty, no Change avariciousness, } \\
\text { growth to maximize 'Falah' only, such Islamic values as; Infaq, } \\
\text { Ihsan, Iqtisad, taawun, abstinence from zulm, iktinaz and } \\
\text { miserliness expected to create appropriate atmosphere for } \\
\text { development; while achieving falah measured both by . } \\
\text { quantitative and qualitative criteria, lot of emphasis on some } \\
\text { positive values like justice or fairness (Al-Adl), compassion } \\
\text { or benevolence (Al-Ihsan), fellow-feeling (Al-Taawun), trust } \\
\text { (Al-Amanah), altruism, reliance (Al- Tawakkul), } \\
\text { contendedness (Al-Qanaa), moderation, patience (Al-Sabr), } \\
\text { sacrifice (Al-lthar), agnanimity (Al-Samahar), .Negative values } \\
\text { such as oppression or xploitation (Al-zulm), malice and hatred } \\
\text { (Al-bagdhao and karahiya), Hoarding (Al-lktinaz), Rivalry (Al- } \\
\text { Hirs), excessive indebtedness or dependency used } \\
\text { synonymously with sin (Al-Agraq Fi Diwan). }\end{array}$ \\
\hline $\begin{array}{l}\text { Borrowings/External } \\
\text { Capital }\end{array}$ & $\begin{array}{l}\text { Approved as a means to attain the ends for } \\
\text { attaining material satisfaction through growth or } \\
\text { utilization in the presence of expanding economic } \\
\text { opportunities regardless of the distribution in the } \\
\text { resources/assets and ownership. }\end{array}$ & $\begin{array}{l}\text { All interest based borrowings/ } \\
\text { Capital transactions condemned and treated synonymously } \\
\text { with unproductive, exploitative and wasteful expenditures by } \\
\text { States/ individuals are condemned in favor of partnership, } \\
\text { cooperation, unleashing entrepreneurial ability; } \\
\text { Borrowings/external capitals under PLS are strongly } \\
\text { encouraged to promote inclusive growth with better } \\
\text { distributional al implication discouraged infavour of self- } \\
\text { reliance. }\end{array}$ \\
\hline Consumer Behaviour & $\begin{array}{l}\text { Utility maximizer only subject to budget (income) } \\
\text { constraint, utilities are independent. }\end{array}$ & $\begin{array}{l}\text { Utility maximizer subject to the maximization of good deeds } \\
\text { (through charity in the path of God) i.e, Falah for both worlds, } \\
\text { utilities are interdependent. }\end{array}$ \\
\hline $\begin{array}{l}\text { Consumption } \\
\text { Theories }\end{array}$ & $\begin{array}{l}\text { Of the four hypotheses developed so far namely, } \\
\text { Abdolute Income, Relative Income, Permanent } \\
\text { Income and Life- Cycle, only Relative. Income } \\
\text { Hypothesis takes cognizance of interdependent } \\
\text { utility behavior. }\end{array}$ & $\begin{array}{l}\text { All the four hypotheses excepting Relative income are in } \\
\text { contrast with IWV because of independent nature of utility } \\
\text { behavior. }\end{array}$ \\
\hline $\begin{array}{l}\text { Luxurious and } \\
\text { Ostentatious } \\
\text { consumption } \\
\text { behaviour }\end{array}$ & $\begin{array}{l}\text { No restriction on item of body shop subject to } \\
\text { budget constraint. }\end{array}$ & $\begin{array}{l}\text { Extravagance (israt), Westeful ostentations consumption } \\
\text { (tabzir), consumption (Itrat) and miserliness (bukhul) strongly } \\
\text { discouraged but expenditure for adequate needs (kafat) } \\
\text { encouraged to promote overall economic activities for job } \\
\text { creation. }\end{array}$ \\
\hline $\begin{array}{l}\text { Social Security } \\
\text { Scheme for Poor } \\
\text { Consumers }\end{array}$ & $\begin{array}{l}\text { Extended social security system pursued with all } \\
\text { the concomitant negative effects on incentive to } \\
\text { work, physical labour, and breakdown of family } \\
\text { institution for the sake of promoting personal level } \\
\text { freedom i.e. unmarried / single mother. }\end{array}$ & $\begin{array}{l}\text { Institution of Infaq (voluntary restraint on consumption } \\
\text { particularly of non-essentials to replace state initiated social } \\
\text { security system with all the negative effects. }\end{array}$ \\
\hline $\begin{array}{l}\text { Psychological law of } \\
\text { the consumer }\end{array}$ & $\begin{array}{l}\text { Cardinal and ordinal measurement of utility, } \\
\text { substitution effects, consumer surplus, elasticity } \\
\text { concepts are widely applied. }\end{array}$ & $\begin{array}{l}\text { Value-neutral concepts like those under the psychological law } \\
\text { of the consumer can be equally applied. }\end{array}$ \\
\hline
\end{tabular}




\begin{tabular}{|c|c|c|}
\hline . Producer Behaviour & $\begin{array}{l}\text { No restriction on the quantity and the and type of } \\
\text { goods and services to produced, effective demand } \\
\text { is the government to regulate all types of imperfect } \\
\text { markets only for the sake of promoting perfect } \\
\text { market, profit is the only consideration behind } \\
\text { production of anything. }\end{array}$ & $\begin{array}{l}\text { No forbidden ie. harmful goods be services to be produced. } \\
\text { All factors in favour of promoting imperfect markets primary } \\
\text { determinant of production, through deceptive advertising, } \\
\text { speculation, of hoarding, discrimination information are false } \\
\text { categorically discouraged infavour of free market. High priority } \\
\text { for producing need-based as apposed to want-based goods } \\
\text { and services, effective need and not demand is the criterion of } \\
\text { production, performing social obligation and not profit } \\
\text { maximization is the primary consideration behind production } \\
\text { of all permissible (halal) goods and services. }\end{array}$ \\
\hline \multicolumn{3}{|c|}{ Concept of factors of production: } \\
\hline Labour: & $\begin{array}{l}\text { Treated like any other factor i.e., capital (machine) } \\
\text { or land, wages as remuneration to be determined } \\
\text { by the marginal productivity theory with no } \\
\text { emphasis on needs of the labour, trade union for } \\
\text { seeking the rights of labour not encouraged under } \\
\text { the assumption of free factor market rules. }\end{array}$ & $\begin{array}{l}\text { Income earned through the use of one's own labour is most } \\
\text { honoured in' the eyes of God, labour's share to be determined } \\
\text { not by marginal productivity theory but by the needs of the } \\
\text { labour with average family size, labour to be treated as } \\
\text { partner (like mudarib using capital) in the production process, } \\
\text { institution ensuring reasonable wages is encouraged to } \\
\text { stabilize fluctuation in wage level; trade unions allowed to } \\
\text { negotiate fair wages based on consultation (shura) for the } \\
\text { mutual interest of employees and employers. }\end{array}$ \\
\hline $\begin{array}{l}\text { Organizer/ } \\
\text { Entrepreneur }\end{array}$ & As a risk-taker deserves profit as its share. & $\begin{array}{l}\text { Capital and entrepreneurship (skilled. labour) merged } \\
\text { together to qualify for profits subject to mudaraba principle of } \\
\text { contract. }\end{array}$ \\
\hline
\end{tabular}

See note under App. Chart I.

\section{APPENDIX: CHART 2}

Course Contents Under Existing Syllabuses Taught at the Departments of Economics, Institutions of Higher Learning based on the teaching methodology under Islamization

\begin{tabular}{|c|c|c|}
\hline $\begin{array}{l}\text { Basic Courses on } \\
\text { Economics }\end{array}$ & $\begin{array}{l}\text { Under Secular World View (SWV) Col. } 1 \text { (focus on positive } \\
\text { aspect) }\end{array}$ & $\begin{array}{l}\text { Under Islamic World View (IWV Col. } 2 \text { (focus } \\
\text { on normative aspect) }\end{array}$ \\
\hline$\frac{\text { Microeconomics }}{\text { Principal level }}$ & $\begin{array}{l}\text { a. Economic problems and economic system in brief; } \\
\text { b. Tools of economic analysis-demand, supply, utility, elasticity; } \\
\text { c. Production function; } \\
\text { d. Pricing of products and factors in in different markets; } \\
\text { e. Poverty, inequality and discrimination limitation of market } \\
\text { mechanism, role of government. }\end{array}$ & $\begin{array}{l}\text { a. Normative concept to be analyzed from Islamic } \\
\text { perspective (chart I) } \\
\text { b. Value-neutral positive concepts to be analyzed } \\
\text { taking examples from Islamic } \\
\text { perspective (Chart 1) } \\
\text { c. Positive concept to be analyzed from c. } \\
\text { Production function; .Islamic perspective (chart 1) } \\
\text { d. Normative concepts to be analyzed from } \\
\text { different markets; Islamic perspective (chart 1) } \\
\text { e. value-loaded normative concepts to be } \\
\text { analyzed from Islamic perspective }\end{array}$ \\
\hline
\end{tabular}




\begin{tabular}{|c|c|c|}
\hline$\frac{\text { Inteffilediate Micro }}{\underline{-1}}$ & $\begin{array}{l}\text { Extension of the Theory of Consumer Behaviour, consumer } \\
\text { surplus, production function, pricing under different market } \\
\text { conditions, average cost pricing. }\end{array}$ & \multirow[t]{2}{*}{$\begin{array}{l}\text { Since most of these issues are the extension of } \\
\text { the same issues under principle level all these } \\
\text { need to be analyzed as above based on chart } 1\end{array}$} \\
\hline Inteffilediate Micro & $\begin{array}{l}\text { Further extension of pricing analysis in perfectly and imperfectly } \\
\text { competitive markets; saving, investment interest rates, decisions } \\
\text { under risk and uncertainty, welfare economics, externalities, } \\
\text { public goods etc. }\end{array}$ & \\
\hline $\begin{array}{l}\text { Macroeconomics } \\
\text { Principle level }\end{array}$ & $\begin{array}{l}\text { a. Arguments for and against market; } \\
\text { b. Measurement of National income. } \\
\text { c. Aggregate supply (AS) and Aggregate } \\
\text { d. Consumption, saving and investment } \\
\text { e. Circular flow of income e. value-neutral as per chart } 1 \\
\text { f. Multiplier-accelerator } \\
\text { g. Fiscal policy to manipute AD } \\
\text { h. Money \& Commercial Banking } \\
\text { i. Central Banking \& Monetary policy } \\
\text { j. Money and level of economic activity } \\
\text { k. Problems of unemployment \& inflation } \\
\text { I. International trade } \\
\text { m. economic growth and development }\end{array}$ & $\begin{array}{l}\text { a. Normative approach as in chart } 1 \\
\text { b. Value-neutral but examples to be drawn from } \\
\text { Islamic perspective } \\
\text { c. Value-neutral to be analyzed with Demand } \\
\text { (AD) -classical vs. Keynesian examples drawn } \\
\text { from ethical perspective } \\
\text { d. Value-loaded concepts to be discussed as } \\
\text { function per chart } 1 \text { f. Value-neutral } \\
\text { g. Value-loaded to be discussed as per chart } 1 \\
\text { h. value loaded to be discussed as per chart } 1 \\
\text { i. value loaded to be discussed as per chart } 1 \\
\text { j. value loaded to be discussed as per chart } 1 \\
\text { k. value-loaded to be discussed as per chart } 1 \\
\text { 1. value-loaded to be discussed as per chart } 1 \\
\text { m. value-loaded to be discussed as per chart } 1\end{array}$ \\
\hline \multicolumn{3}{|c|}{$\begin{array}{l}\text { Intermediate Macro - I } \\
\text { Extention of principal level concept s of \& the theories } \\
\text { Intermediate Macro - II }\end{array}$} \\
\hline Public Finance & $\begin{array}{l}\text { a. Extremely limited role of government although size of } \\
\text { government is expanding continuously to overcome recent } \\
\text { economic crises. } \\
\text { b. Mobilization of revenues through direct and indirect taxes of } \\
\text { which all direct taxes are designed to be progressive with harmful } \\
\text { effects on incentives to produce and invest. } \\
\text { c. Interest based borrowinl's widely advocated and practiced. } \\
\text { d. Heads of expenditures of revenues highly discriminatory and } \\
\text { disproportionately infavour of rich (urban \& class-biased) and } \\
\text { against poor. }\end{array}$ & $\begin{array}{l}\text { Role of government value-loaded concept and to } \\
\text { be discussed as per chart } 1 \\
\text { b. Value-loaded since direct taxes are usually } \\
\text { progressive falling on rich and indirect taxes } \\
\text { regressive falling on poor, need to be replaced by } \\
\text { Islamic taxes such as zakat, kharaj, jizya, ushar } \\
\text { etc. with no harmful effects on incentives to } \\
\text { produce, save and invest. } \\
\text { c. Discouraged as it is treated synonymously with } \\
\text { sin and need to be discussed from normative } \\
\text { perspective (chart I) involving no interest. } \\
\text { d. Value-loaded and hence need to be discussed } \\
\text { from Islamic perspective with all positive and } \\
\text { negative values on different income classes. }\end{array}$ \\
\hline Economic & $\begin{array}{l}\text { Concept of development, factors behind development highly } \\
\text { materialistic mechanical, with no focus on human capital, basic } \\
\text { needs, participation and redistribution, different theories of } \\
\text { development namely, Balanced vs. unbalanced, economic } \\
\text { dualism, structuralist vs. dependency etc. biased towards free } \\
\text { market capitalistic approach. Negative effects of human-centered } \\
\text { development on environment etc. not given enough emphasis. }\end{array}$ & $\begin{array}{l}\text { Concept of development should be discussed } \\
\text { from comprehensive perspective with focus on } \\
\text { human development, human needs, and their full } \\
\text { participation instead of alienation, growth with } \\
\text { jobs, growth with redistribution, moderation in } \\
\text { growth to ensure sustainability and minimize the } \\
\text { negative effects of growth on environments \& } \\
\text { health. }\end{array}$ \\
\hline $\begin{array}{l}\text { History of } \\
\text { Conventional/ } \\
\text { Western Economic } \\
\text { Thought }\end{array}$ & Biased with positive analysis & $\begin{array}{l}\text { Existing course on Islamic economic thought to } \\
\text { give methodology of Islamic economic analysis. }\end{array}$ \\
\hline Money \& Banking & $\begin{array}{l}\text { Biased with positive analysis and forbidden instruments and } \\
\text { methods of transactions. }\end{array}$ & $\begin{array}{l}\text { Existing course on Islamic Banking to establish } \\
\text { the superiority of Islamic system of transactions. }\end{array}$ \\
\hline $\begin{array}{l}\text { Comparative } \\
\text { Economic System }\end{array}$ & $\begin{array}{l}\text { Biased with positive analysis on anti-ethical ideologies/doctrines } \\
\text { (vide col. } 1 \text { of chart I) }\end{array}$ & $\begin{array}{l}\text { Existing course on issues on different aspects } \\
\text { Islamic Economics to establish the superiority of } \\
\text { Islamic economic system. }\end{array}$ \\
\hline
\end{tabular}


International Trade $\quad$ Based on the positive analysis and of comparative advantage, factor endowments treating human beings (labour) like any other factor, implicit approval of beggar- thy-neighbour policy
To be discussed in the light of comparative advantage based on mass production of essentials based on resource endowment in place of capital-intensive techiques for job creation; Promotion of trade based on cooperation, mutual reciprocity (shura) and not beggar thy-neighbour policy based on cut-throat competitions; above, promotion of rich thyneighbour policy

Notes: It is presumed that the course contents included in the existing syllabus of Bachelor of Economics of IIUM are based on the steps towards comprehensive Islamization of Economics. The course on quantitative economics such as statistics, mathematics and econometrics are assumed to be value-neutral and as such not included here. A number of courses on Islamic economics such as Foundations of Islamic economics, Issues in Islamic Economics, Usul al-fiqh and Fiqh for economists need not be included since these courses already fulfill shariah compatibility. As a part of teaching Islamic Economic Thought, the introduction of a new course on various contemporary aspects of Islamic Economic Thought based on Mohamed Aslam Hanee£'s work (1995) will be quite enriching in the process of Islamization effort. The issues under App. Chart I and Chart 1 in the text are only tentative and hence are subject to further improvement. The statements used in the this chart are presented in the style of course outlines/ contents and hence, not in the form of complete sentences.

\section{REFERENCES}

Abu Sulayman, Abdul Hamid A. Crisis in the Muslim Mind (Trans. by Yusuf Talal DeLorenzo), IIIT \& International Islamic Publishing House, USA, 1989.

Aidit GhaZali et al. Rearlings in the Concept And Methodology of Islamic Economics. Pelanduk Publications, Petaling Jaya, Malaysia, 1989.

Al-Alwani, T.J. Usul Al Fiqh Al Islam -source methodology in Islamic jurisprudence, (English edition by Yusuf Talal DeLorenzo e. al), IIIt, 1990.

Acikgenc, Alparsian, 'The Concept of World View and Its Significance in Islamization of Knowledge'. A paper presented at the Kulliyyah of Economics, International Islamic University, Seminar on Jan, 1996. (Mimeo)

Ajijola A.D. The Islamic Concept of Social Justice, Islamic Publications Ltd, Pakistan, 1977.

Al-Attas, S.M.A. Islam and Secularism, Muslim Youth Movement of Malaysia (ABIM), Kuala Lumpur, 1978.

Al-Edrus. S.M.D Islamic Epistemology -A Introduction to the Theory of Knowledge in Al- Qur'an, The Islamic Academy, Cambridge \& University Sains Malaysia, 1990.

Ali Nadvi S.A.H. Islam and The World, Academy of Islamic Research \& Publications, Lucknow, India, 1982.

American Trust Publication (ATP), Contemporary Aspects of Islamic Thinking in Islam, ATP, USA, 1976.

Arif. M. 'The Islamization of Knowledge and Some Methodological Issues in Paradigm Building...' in The American Journal of Islamic Social Sciences (AJISS), Vol. 4, No.1, 1987, IIIT, Washington.

As-Sadr, M.B. Iqtisaduna Vol. I \& II (our Economics), World organization for Islamic Services (WOFIS), Iran.

Blyton. P. et al. Time, Work and Organization, Routledge, London, 1992.

Chapra, U. Islam and Economic Development (Islamization of Knowledge -14), IIIT, Pakistan, 1993.

Islam and the Economic Challenge, The Islamic Foundation, UK and IIIT, USA, 1992.

Faruqi, I.R. Christian Ethics, Mc Gull University Press, 1967.

Haneef, M.A. Contemporary Islamic Economic Thought, S. Abdul Majeed \& Co. for Karq, Kuala Lumpur, 1995.

Hasan-uz-Zaman, M. The Economic Foundations of the Islamic State, International Islamic Publishers, Pakistan, 1981.

Heilbroner, R. The Making of Economic Society, Prentice Hall International Inc., 1989

IIIT, International Islamic University Malaysia, Collection of Articles Published in The AJISS, 1984-1995, (in Photocopy binding), 1995.

IIIT, The American Journal of Islamic Social Science, Vol. 8 No.2. Sept. 1991
IIIT, Islamization of Knowledge -General Principles and Work Plan, Islamic Knowledge Series (IKS), No., 1989.

IIIT, Toward Islamization of Disciplines, IKS-5, 1989.

International Institute of Islamic Thought (lilT), The American Journal of Islamic Social Sciences, Vol. 12, Spring 1992, No.1, Jointly with, The Institute of Policy Research, Malaysia., Iwai, Satoshi, A New Approach to Human Economics; A Case Study of an Islamic Economy, The Institute of Middle Eastern Studies, International University of Japan, 1985.

Kahf, M. The Islamic Economy -Analytical Understanding of the Functioning of the Islamic Economic System, Muslim Students Association of US \& Canada (MSA) Gary, Indiana, 1979, Chap. 1.

Kamal Hassan M., Voice of Islamic Moderation From the Malay World, EMIR, Malaysia, 2011

Kamal Hassan M. The need to understand Al-Wassatiyyah-As part of IIUM's Mission of Islamization, IIUM, Selangor, 2013.

Khan M.A. Economic Teachings of Prophet Muhammad. A Select Anthology of Hadith Literature on Economics, International Institute of Islamic Economics \& Institute of Policy Studies, Islamabad, 1989

Masud, F. Worker's Right in Islam, Islamic Foundation Bangladesh, 1987 (Trans by Muhammad Ruhul Amin)

Maududi S.A.A. Towards Understanding Islam, International Islamic Federation of Student Organizations, Kuwait, 1989.

Metawally, M.M. Essays on Islamic Economics, Academic Publishers, 1993. Mia, A.J. Concept of Unity, Islamic Foundation, Dhaka, Bangladesh, 1980.

Mohammad Aslam Haneef. Contemporary Islamic Economic Thought, S. Abdul majid \& Co. for lqraq, Kuala Lumpur., 1995.

Molla, R.I. et al. Frontiers and Mechanics of Islamic Economics, University of Sokoto, Nigeria,1988.

Moten, A.R. \& B.Shari, M.O.K., Nature and Methodology of Islamic Economics. Bayero University, Keno, Nigeria, 1990. E Naqvi, S.N.H. Development Economics -A New Paradigm, Sage Publications, New Selhi, 1993.

Nomani, F \& Rahnema, A. Islamic Econmic Systems, Business International Press, K.L. 1995.

Outb. M. Islam The Misunderstood Religion, IIFSO, 1974.

Pramanik A.H., Human Development with Dignity, Cahaya Pantai, $\mathrm{KL}, 1994$.

Rahman, A. Economic Doctrines of Islam, 3 vols. Islamic Publications, Lahore, Pakistan, 1975.

Rahnema, A \& Nomani. F. The Secular Miracle: Religion, Politics and Economic Policy in Iran, Zed books Ltd., London, 1990.

Rehman S. S. \& Askari H., How Islamic are Islamic Countries? Global Economy Journal, Vol. 10, Issue.2 Article 2, 2010.

Rosser \& Rosser, Comparative Economics in a Transforming World Economy, Irwin, 1996. 
Sadeq, A.H.M. 'Islamization of Economics: Some Methodological Issues', A paper presented at the Kulliyyah Seminar of International Islamic University, Malaysia (IIUM) , 1995. (Unpublished)

Sardar, Z., The Future of Muslim Civilization, Croom Helm London, 1979.

Siddiqui, M.N. Muslim Economic Thinking -A Survey of Contemporary Literature, The Islamic Foundation, UK, 1981.
Siddiqui, M.N. Some Aspects of the Islamic Economy, Islamic Publications Ltd., Pakistan, 1978.

Tahir, S. et al. Readings in Microeconomics -An Islamic Perspective, Longman, Malaysia, 1992.

Vadillo. O. The End of Economics An Islamic Critique of Economics, Madinah Press, 1991.

Valibeigi, M. Islamization of The Economy: The Post-Revolutionary Iranian Experience. Ph.D thesis submitted at the American University, Washington, 1991.

Received on 23-01-2016

Accepted on 11-04-2016

Published on 20-09-2016

DOI: http://dx.doi.org/10.6000/1929-7092.2016.05.26

(C) 2016 Ataul Huq Pramanik; Licensee Lifescience Global.

This is an open access article licensed under the terms of the Creative Commons Attribution Non-Commercial License (http://creativecommons.org/licenses/by-nc/3.0/) which permits unrestricted, non-commercial use, distribution and reproduction in any medium, provided the work is properly cited. 